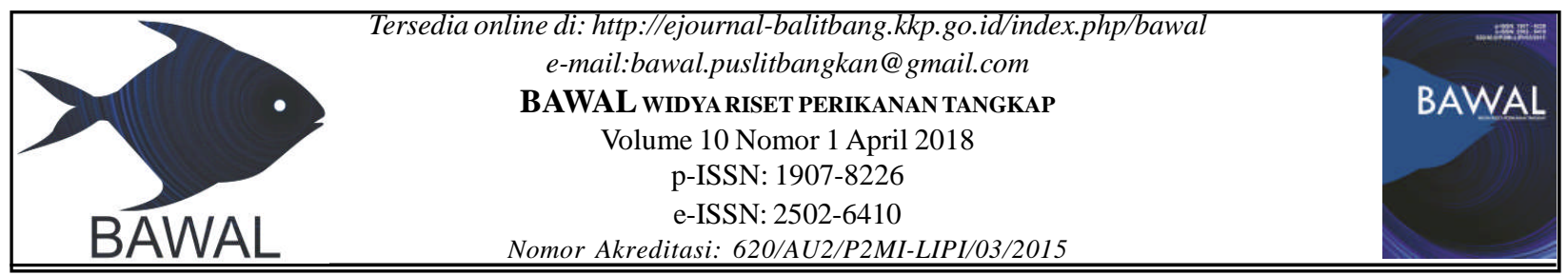

\title{
BIOLOGI REPRODUKSI, PERTUMBUHAN DAN MORTALITAS IKAN EKOR KUNING (Caesio cuning Bloch, 1791) DI PERAIRAN NATUNA
}

\section{REPRODUCTIVE BIOLOGY, GROWTH AND MORTALITY OF YELLOWTAIL FUSILIER (Caesio cuning Bloch, 1791) IN THE NATUNA WATERS}

\author{
Prihatiningsih $^{* 1,}$ Isa Nagib Edrus ${ }^{1}$ dan Bambang Sumiono ${ }^{2}$ \\ 'Balai Riset Perikanan Laut, Cibinong, Bogor, Jl. Raya Bogor KM. 47 Cibinong, Bogor- Jawa Barat, Indonesia \\ ${ }^{2}$ Pusat Riset Perikanan, Jl. Pasir Putih II, Ancol Timur, Jakarta Utara-14430, Indonesia \\ Teregistrasi I tanggal: 25 Nopember 2016; Diterima setelah perbaikan tanggal: 25 Januari 2018; \\ Disetujui terbit tanggal: 20 Februari 2018
}

\begin{abstract}
ABSTRAK
Ikan ekor kuning (Caesio cuning) merupakan ikan ekonomis penting dan mendominasi hasil tangkapan bubu di perairan Natuna. Pada saat ini, produksinya merupakan dominan ke-2 setelah ikan bawal putih yaitu 2.891 ton/tahun (17,8\% dari total produksi ikan). Populasi ikan ekor kuning sejak tahun 2008 menurun, diduga karena tingkat eksploitasi yang cenderung meningkat. Penelitian ini bertujuan mengkaji aspek biologi, meliputi reproduksi, pertumbuhan dan mortalitas ikan ekor kuning. Contoh ikan sebanyak 2.627 ekor dikumpulkan melalui tempat pendaratan ikan utama di Kijang, Pulau Bintan (Kepulauan Riau) dan Tanjung Pandan (Kepulauan Bangka Belitung) pada bulan Januari - Nopember 2014. Hasil penelitian menunjukkan sebaran ukuran panjang ikan ekor kuning berkisar antara 9,3-43,3 cmTL. Ikan yang tertangkap didominasi oleh belum matang gonad (immature). Musim pemijahannya berlangsung pada bulan Juni-Juli dan September-Oktober. Fekunditas telur yang matang gonad berkisar antara 13.355-151.632 butir. Panjang pertama kali ikan ekor kuning tertangkap dengan bubu adalah lebih kecil dari panjang pertama kali matang gonad $\left(\mathrm{L}_{c}<\mathrm{L}_{\mathrm{m}}\right)$, sehingga akan mengancam kelestariannya. Analisis pertumbuhan dengan uji-t diperoleh pertambahan panjang secepat pertambahan beratnya (isometrik). Aplikasi model analitik menggunakan program Electronic LEngth Frequency ANalisis-I (ELEFAN-I) diperoleh parameter pertumbuhan $(=\mathrm{K})$ sebesar $0,6 /$ tahun, panjang asimtotis $\left(=\mathrm{L}_{\infty}\right)$ sebesar $43,21 \mathrm{cmFL}$ dan umur hipotesis ikan pada saat panjang sama dengan nol $\left(=\mathrm{t}_{\mathrm{o}}\right)$ sebesar $-0,24$ tahun, sehingga persamaan pertumbuhan Von Bertalanffy sebagai $\mathrm{L}_{\mathrm{t}}=43,21\left(1-\mathrm{e}^{-0,6(\mathrm{t}-0,24)}\right)$. Parameter mortalitas menunjukkan laju kematian alami $(=\mathrm{M})$ sebesar 1,17/tahun, laju kematian karena penangkapan (=F) sebesar 1,21/tahun dan laju kematian total (=Z) sebesar 2,38/tahun. Berdasarkan nilai F dan Z tersebut maka diperoleh estimasi laju eksploitasi (exploitation rate) sebesar 0,58 atau dalam kondisi sudah melampaui nilai optimum $(\mathrm{E}=0,5)$, sehingga pengelolaannya perlu segera dilakukan agar potensi lestarinya terjaga.
\end{abstract}

Kata Kunci: Reproduksi; pertumbuhan; mortalitas; Caesio cuning; Natuna

\section{ABSTRACT}

The yellowtail fusilier (Caesio cuning) is one of the economically important fish caught by trap nets in the Natuna waters. The production of the yellowtail fusilier in Bintan regency was a second dominant fish species after white pomfret by 2.891 tons/year (17.8\% of total landed). Population of the yellowtail fusiliers is tend to decrease since 2008 due to an increase of fishing pressure to this species. This study aims to assess the biological aspects such as reproduction, growth and mortality of the yellowtail fusiliers. Monthly length frequencies data of 2.627 individual was collected through main landing place in Kijang, Bintan Island (Riau islands) and Tanjung Pandan (Bangka Belitung Islands) within January - November 2014. The results showed that the length distribution of the yellowtail fusilier ranged between 9.3 - $43.3 \mathrm{cmTL}$. The fish caught was dominated by the immature stage. The spawning seasons possibly occurred between June-July and September-October. Fecundity of mature fish ranged between 13.355-151.632 eggs. The length of first capture by trap nets was under the length at first mature $\left(L_{c}<L_{m}\right)$, and threaten its sustainability. Based on t-test it is showed that the weight growth pattern as fast as length growth (isometric). Electronic LEngth Frequency ANalisys-I(ELEFAN-I) used, showed that the growth parameter $(K)$ was 
$0.6 / y$, asymtotic length $\left(L_{\infty}\right)$ was $43.21 \mathrm{cmFL}$, and age at zero length $\left(t_{o}\right)$ was -0.24 yr, so the Von Bertalanffy's equation growth curve were $L_{t}=43.21\left(1-e^{-0,6(t-0,24)}\right)$. Mortality parameters showed the natural mortality rate $(M)$ was $1.17 / y r$, fishing mortality rate $(F)$ was $1.21 / y$ r, and total mortality rate $(Z)$ was $2.38 / y$ r. Based on the values of $F$ and $Z$ obtained exploitation rate of 0.58 was likely exceed the optimum level $(E=0.50)$ so that, management measures to maintain its potential yield should be applied.

\section{Keywords: Reproduction; growth; mortality; Caesio cuning; Natuna}

\section{PENDAHULUAN}

Perairan Natuna sebagai bagian dari Wilayah Pengelolaan Perikanan Negara Republik Indonesia (WPPNRI) 711-Laut China Selatan, secara geografis memiliki arti strategis. Selain merupakan wilayah perbatasan dengan negara tetangga juga menyediakan sumberdaya ikan laut yang dapat dimanfaatkan oleh masyarakat di sekitarnya. Pemanfaatan sumber daya ikan di perairan ini sekaligus merupakan pengamanan di wilayah perbatasan. Ikan ekor kuning (Caesio cuning) termasuk salah satu jenis ikan karang dari famili Caesionidae, menjadi target penangkapan dengan bubu dan pancing ulur di perairan Natuna dan sekitarnya. Salah satu tempat pendaratan ikan utama adalah Kijang yang berada di Pulau Bintan (Kepulauan Riau). Data statistik perikanan Kabupaten Bintan tahun 2014, menyebutkan produksi ikan ekor kuning pada tahun 2014 menempati urutan ke dua setelah bawal putih yaitu sebesar 2.891 ton/tahun (17,8\% dari total produksi ikan di Kabupaten Bintan). Penelitian yang dilakukan oleh Balai Penelitian Perikanan Laut Jakarta (BPPL, 2015), menunjukkan sejak tahun 2008 hingga 2014 terdapat penurunan yang signifikan terhadap produksi ikan ekor kuning yaitu rata-rata $26 \%$ per tahun. Penurunan itu diikuti pula oleh hasil tangkapan per unit bubu yang cenderung berkurang Pada tahun 2014 terdapat 111 unit kapal bubu yang berbasis di Kijang. Kondisi tekanan penangkapan yang tinggi serta volume produksi yang terus menurun dikhawatirkan dapat mengakibatkan penipisan stok ikan ekor kuning di Perairan Natuna dan mengancam kelestarian sumberdayanya.

Perairan Indonesia memiliki kurang lebih 132 jenis ikan yang bernilai ekonomi tinggi, 32 jenis diantaranya hidup di daerah terumbu karang. Jenis ikan karang yang menjadi penyumbang produksi perikanan antara lain dari famili Caesionidae, Lutjanidae, Serranidae, Holocentridae, Siganidae, Scaridae, Lethrinidae, Priachantidae, Labridae dan Haemulidae. Di antara famili tersebut, ikan ekor kuning yang termasuk famili Caesionidae merupakan sumberdaya ikan penting dan dieksploitasi secara komersil. Populasinya dalam bentuk gerombolan (schooling) tidak begitu besar, memiliki penyebaran luas dan umumnya berharga tinggi (Nggajo, 2009). Dalam perdagangan, ikan ekor kuning dikenal dengan nama yellowtail fusilier. Daerah penyebarannya ditemukan di perairan Pasifik barat, mulai dari Srilanka, hingga perairan Indonesia, Vanuatu, selatan Jepang dan perairan utara Australia. Ikan ekor kuning di
Srilanka ditangkap dengan menggunakan pancing ulur, di Thailand dan Malaysia menggunakan bubu, di Indonesia, Filipina dan Papua New Guinea biasanya menggunakan bubu, gillnet dasar dan pancing ulur (Carpenter \& Niem, 2001). Habitat utama ikan ini adalah daerah yang berbatu dan terumbu karang, biasanya membentuk gerombolan kecil hingga besar pada kedalaman antara 2-60 m. Makanan utamanya berupa zooplankton. Dari seluruh anggota famili Caesionidae, jenis ikan ekor kuning ini adalah yang paling tahan terhadap kondisi perairan keruh (Allen et al., 2007).

Penelitian di Kepulauan Seribu meyebutkan ikan ekor kuning merupakan target penangkapan nelayan setempat. Produksi pada tahun 2003-2007 cenderung meningkat, diikuti dengan penambahan upaya penangkapannya (jumlah unit kapal gillnet dan bubu). Selanjutnya disebutkan bahwa kegiatan penangkapan ikan ekor kuning di Kepulauan Seribu sudah mengarah ke tangkap lebih (growth overfishing) karena umumnya menggunakan jaring yang tidak selektif sehingga ikan muda ikut tertangkap. Disebutkan pula oleh Estradivari et al. (2007), bahwa ancaman kelestarian populasi ikan ekor kuning di Kepulauan Seribu juga disebabkan oleh degradasi terumbu karang sebagai habitatnya serta penggunaan muroami di perairan ini. Pada tahun 2005 penurunan prosentase penutupan karang keras dibanding beberapa tahun sebelumnya mencapai $33,2 \%$.

Kegunaan mempelajari ukuran ikan dan aspek biologinya dalam pengelolaan sumber daya ikan dikemukakan oleh Sparre \& Venema (1999). Kajian ukuran ikan dengan menggunakan pendekatan tertentu dapat digunakan untuk menduga populasi ikan, antara lain tentang pertumbuhan dan kematian ikan. Demikian pula dengan mempelajari aspek reproduksi maka prediksi musim pemijahan berguna dalam pengelolaan melalui musim penutupan (close session). Panjang pertama kali matang gonad (length at first maturity) dapat digunakan untuk mengatur ukuran mata jaring yaitu bila dikaitkan dengan panjang pertama kali tertangkap (length at first capture).

Upaya pengelolaan stok ikan ekor kuning di perairan Natuna sampai saat ini belum dapat dilakukan, mengingat belum diketahuinya indikator biologi dan indikator perikanannya. Indikator biologi yang diperlukan dalam pengelolaannya, antara lain meliputi ukuran ikan, reproduksi, laju pertumbuhan dan laju kematian. Tulisan 
ini membahas secara ringkas tentang (1) biologi reproduksi; (2) pertumbuhan dan (3) mortalitas. Hasil kajian ini diharapkan dapat digunakan sebagai informasi dasar dalam merumuskan upaya pengelolaan sumberdaya ikan ekor kuning di perairan Laut Natuna.

\section{BAHAN DAN METODE}

Penelitian ikan ekor kuning (Caesio cuning) dilakukan dari bulan Januari sampai dengan Nopember 2014. Contoh ikan sebanyak 2.627 ekor terdiri dari ikan jantan sebanyak 285 ekor, ikan betina sebanyak 1.076 ekor dan tidak teridentifikasi jenis kelaminnya sebanyak 1.266 ekor.
Contoh ikan dikumpulkan dari hasil tangkapan bubu dan pancing ulur yang didaratkan melalui tempat pendaratan ikan (tangkahan) di Kijang, Pulau Bintan dan Tanjung Pandan. Pengumpulan data bulanan terhadap frekuensi panjang total, berat individu dan kematangan gonad dilakukan seminggu sekali, yaitu sebanyak $10 \%$ dari total ikan ekor kuning yang didaratkan pada saat itu. Pengukuran panjang ikan menggunakan papan ukur berketelitian 1,0 cm (Gambar 1) dan berat diukur menggunakan timbangan digital berketelitian 1,0 g. Gonad ikan betina diawetkan dalam larutan Gilson, selanjutnya dilakukan pengamatan di Laboratorium Balai Penelitian Perikanan Laut, Jakarta.

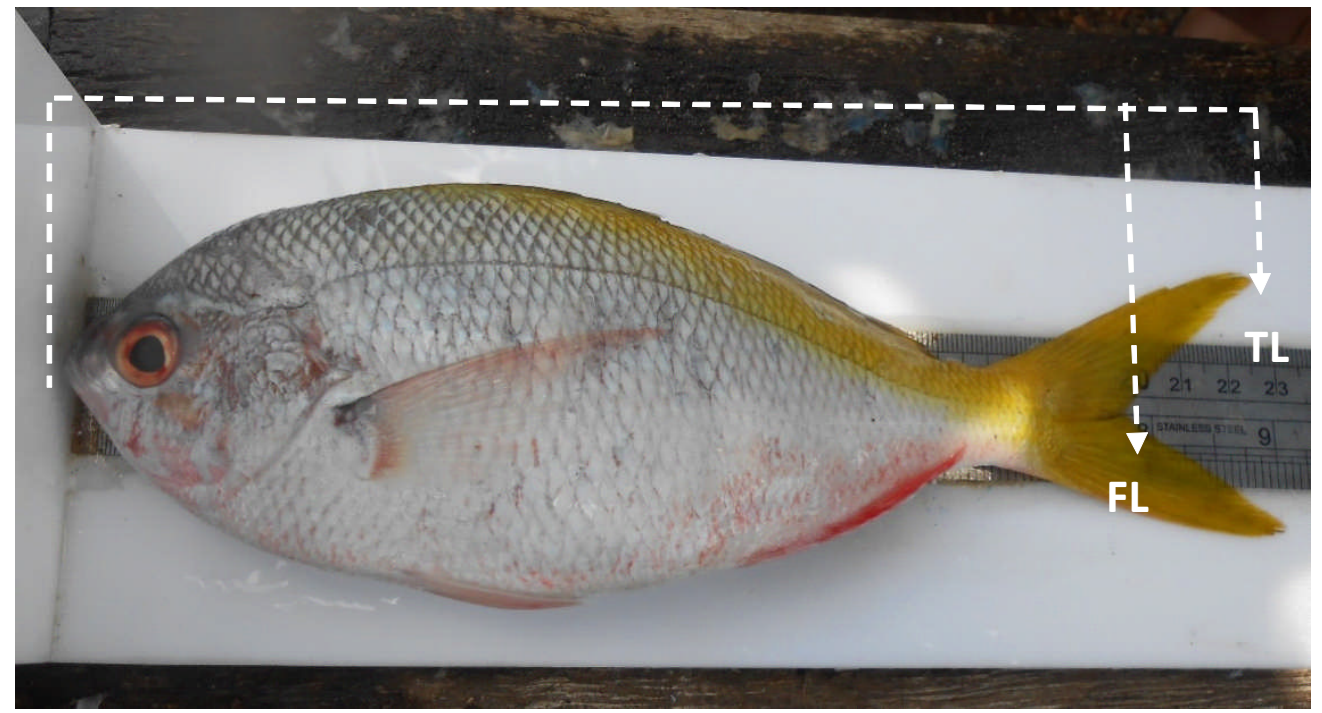

Gambar 1. Ikan ekor kuning dan pengukuran panjang ikan (panjang cagak dan panjang total).

Figure 1. The yellowtail fusilier and its length measurement (fork length, FL and total length, TL). (Sumber/Source: Dokumentasi pribadi/Personal documentation)

Tingkat kematangan gonad diamati secara visual/ makroskopis untuk melihat perubahan morfologi gonad berdasarkan lima skala kematangan yang mengacu pada Holden \& Raitt (1974), yaitu : tingkat kematangan gonad I (belum matang/ immature), tingkat kematangan gonad II (perkembangan/developing), tingkat kematangan gonad III (pematangan/ripening), tingkat kematangan gonad IV (matang/ripe) dan tingkat kematangan gonad V (mijah/ spent). Untuk mengetahui perubahan yang terjadi didalam gonad secara kuantitatif dapat dinyatakan dengan suatu indek yang disebut Indek Kematangan Gonad (IKG) atau gonado somatic index (GSI) yang mengacu pada persamaan sebagai berikut (Effendie, 1997):

$$
I K G=\frac{B_{g}}{B_{t}} x 100
$$

dimana;

$\mathrm{B}_{\mathrm{g}}=$ bobot gonad segar (gram)

$\mathrm{B}_{\mathrm{t}}^{\mathrm{g}}=$ bobot tubuh ikan (gram)
Untuk melihat masa pematangan gonad atau kondisi fisiologis ikan dalam masa pertumbuhan dan bereproduksi, maka dihitung faktor kondisinya $\left(\mathrm{K}_{\mathrm{n}}\right)$ berdasarkan ukuran panjang dan berat individu seperti dikemukakan oleh Goddard (1996) sebagai berikut:

$$
K_{n}=\frac{W}{a L^{b}}
$$

Bila nilai $b=3$ (isometrik) maka persamaannya menjadi:

$$
K_{n}=\frac{10^{5} W}{L^{3}}
$$

dimana;

$\mathrm{K}_{\mathrm{n}}=$ faktor kondisi

$\mathrm{W}=$ berat rata-rata $(\mathrm{kg})$

$\mathrm{L}=$ panjang rata-rata $(\mathrm{cm})$

$\mathrm{a}, \mathrm{b}=$ konstanta; 
Penghitungan butiran telur (fekunditas) ditunjukan pada ikan betina yang matang gonad yaitu pada tingkat kematangan gonad III dan IV dengan menggunakan metode gravimetrik. Contoh gonad yang telah ditimbang diambil cuplikannya secara merata yaitu dari bagian ujung dan tengah gonad, kemudian diamati menggunakan mikroskop dengan perbesaran 10x10 dan dihitung jumlah butirannya. Dalam pengamatan ini digunakan contoh gonad seberat $0.1 \mathrm{~g}$. Fekunditas dihitung berdasarkan persamaan sebagai berikut (Holden \& Raitt, 1974):

$$
F=\frac{n x G}{g}
$$

dimana;

$$
\begin{aligned}
& \mathrm{F}=\text { fekunditas (butir) } \\
& \mathrm{n}=\text { jumlah telur dalam sub contoh } \\
& \mathrm{G}=\text { bobot gonad (gram) } \\
& \mathrm{g}=\text { bobot sub contoh gonad (gram) }
\end{aligned}
$$

Analisis hubungan antara fekunditas dengan panjang ikan didasarkan pada persamaan berikut (Effendie, 2002):

$$
F=a L^{b}
$$

dimana;

$$
\begin{aligned}
\mathrm{F} & =\text { fekunditas } \\
\mathrm{L} & =\text { panjang ikan }
\end{aligned}
$$

$\mathrm{a}$ dan $\mathrm{b}=$ konstanta hubungan antara fekunditas dan panjang ikan.

Ukuran panjang pertama kali ikan ekor kuning tertangkap (length at first capture, $\mathrm{L}_{\mathrm{c}}$ ) diperoleh dengan cara memplotkan frekuensi kumulatif dengan panjang totalnya sehingga diperoleh kurva logistik baku. Titik potong antara kurva logistik baku dengan $50 \%$ frekuensi kumulatif merupakan nilai rata-rata ukuran panjang ikan yang tertangkap (Sparre \& Venema, 1999).

Panjang pertama kali matang matang gonad (length at first maturity, $\mathrm{L}_{\mathrm{m}}$ ) diduga dengan cara Spearman-Karber seperti yang dilakukan oleh Udupa (1986) sebagai berikut:

$$
m=X_{k}+\frac{X}{2}\left\{X \sum p_{i}\right\}
$$

dimana;

$\mathrm{m}=$ logaritma panjang ikan pertama kali matang gonad

$\mathrm{X}_{\mathrm{k}}=$ logaritma nilai tengah panjang dimana ikan $100 \%$ matang gonad

$\mathrm{x}=$ selisih logaritma dari pertambahan nilai tengah panjang

$\mathrm{p}_{\mathrm{i}}=$ proporsi ikan matang gonad pada kelas ke-i. Panjang pertama kali matang gonad diperoleh dengan cara menghitung antilog nilai $\mathrm{m}$.
Pola pertumbuhan ikan diketahui dengan cara menganalisis hubungan panjang-berat menurut formula sebagai berikut (Effendie, 1979):

$\mathrm{W}=\mathrm{a}^{*} \mathrm{~L}^{\mathrm{b}}$

dimana;

$\mathrm{W} \quad=\operatorname{berat}($ gram$)$

$\mathrm{L} \quad=$ panjang $(\mathrm{cm})$

$\mathrm{a}$ dan $\mathrm{b}=$ konstanta regresi

Hubungan panjang-berat dapat dilihat dari nilai konstanta $b$ nya. Untuk menguji nilai $b=3$ atau $b \neq 3$ dilakukan uji -t (uji parsial), dengan hipotesis:

$\mathrm{H}_{0}: \quad \mathrm{b}=3$, hubungan panjang dan berat adalah isometrik (pertambahan panjang sebanding dengan pertambahan beratnya)

$\mathrm{H}_{1}: \quad \mathrm{b} \neq 3$, hubungan panjang dengan berat adalah allometrik (pertambahan panjang tidak sebanding dengan pertambahan beratnya). Bila nilai $b>3$ maka hubungannya bersifat allometrik positif (pertambahan berat lebih cepat daripada pertambahan panjang). Bila nilai $b<3$ maka hubungannya bersifat allometrik negatif (pertambahan panjang lebih cepat daripada pertambahan beratnya).

Parameter pertumbuhan ikan ekor kuning meliputi laju pertumbuhan $(=\mathrm{K})$ dan panjang asimtotis $\left(\mathrm{L}_{\infty}\right)$ diduga dengan program Electronic LEngth-Frequency ANalysis-I (ELEFAN-1) yang dikemas dalam perangkat lunak FAO-ICLARM Stock Assessment Tools-II (FiSATII) yang mengacu pada Gayanilo et al., (2005). Umur teoritis $\left(=\mathrm{t}_{\mathrm{o}}\right)$ yaitu umur pada saat panjang sama dengan nol diduga dengan persamaan empiris Pauly (1984):

$\log \left(-\mathrm{t}_{0}\right)=-03,922-0,2752 \log \mathrm{L}_{\infty}-1,038 \log \mathrm{K}$

Ketiga parameter pertumbuhan $\left(\mathrm{L}_{\infty}, \mathrm{K}\right.$ dan $\left.\mathrm{t}_{0}\right)$ digunakan sebagai masukkan pada model pertumbuhan von Bertalanffy sebagaimana dikemukakan oleh Sparre \& Venema (1999) sebagai berikut:

$$
L(t)=L \infty\left(1-e^{-K\left(t-t_{O}\right)}\right)
$$

dimana $\mathrm{L}(\mathrm{t})$ adalah ukuran panjang ikan pada saat umur t tahun.

Mortalitas alami (=M) diduga dengan menggunakan persamaan empiris dari Pauly (1980) in Sparre \& Venema (1999), yaitu menggunakan masukan data suhu perairan rata-rata $\left(=\mathrm{T},{ }^{\circ} \mathrm{C}\right)$ di lokasi penelitian, sebagai berikut: 
$\operatorname{Ln} M=-0,152-0,279 * \operatorname{Ln} L_{\infty}+0,6543 * \operatorname{Ln} K+0,463 * \operatorname{Ln} T$..(10)

Disebutkan untuk jenis ikan yang menggerombol seperti ikan ekor kuning, dalam perhitungan nilai M perlu dikalikan dengan faktor 0,8 sehingga nilainya menjadi $20 \%$ lebih rendah.

Pendugaan mortalitas total $(=\mathrm{Z})$ sebagai kemiringan (slope) pada kurva konversi hasil tangkapan (length converted catch curve) dirunut dengan program FiSATII. Nilai $Z$ dan $M$ digunakan untuk mengestimasi kematian karena penangkapan $(=F)$ melalui persamaan $Z=M+F$. Tingkat pemanfaatan (exploitation rate, E) diperoleh dari perbandingan antara nilai $\mathrm{F}$ dengan $\mathrm{Z}$ yaitu menggunakan persamaan : $\mathrm{E}=\mathrm{F} / \mathrm{Z}$ (Sparre \& Venema, 1999).

\section{HASIL DAN BAHASAN \\ Hasil}

\section{Reproduksi}

Aspek reproduksi memiliki peranan yang sangat penting dalam peningkatan populasi ikan. Beberapa aspek reproduksi ikan diantaranya tingkat kematangan gonad (TKG), indek kematangan gonad (IKG), faktor kondisi, fekunditas dan diameter telur, memberikan informasi tentang frekuensi pemijahan, lama pemijahan dan ukuran ikan pertama kali matang gonad (Nikolsky, 1963).

\section{Kematangan Gonad}

Tingkat kematangan gonad ikan ekor kuning betina di perairan Natuna didominasi oleh stadia belum matang gonad (TKG stadia I dan II). Hal ini mengindikasikan bahwa ikan yang tertangkap oleh bubu dan pancing ulur umumnya masih dalam masa pertumbuhan atau belum tahap dewasa. Ikan dalam TKG stadia III dan IV (matang gonad) meningkat pada bulan April dan Mei, demikian pula pada bulan September. Ikan dalam TKG $\mathrm{V}$ (salin) ditemukan pada bulan Mei dan September (Tabel 1).

Nilai indek kematangan gonad (IKG) dan faktor kondisi $\left(\mathrm{K}_{\mathrm{n}}\right)$ semakin meningkat seiring dengan bertambahnya TKG hingga ke TKG-IV. Pada TKG-V/spent terjadi penurunan IKG, karena pada tahap tersebut telur yang terdapat di dalam gonad sudah berkurang jumlahnya. Nilai IKG dan $\mathrm{K}_{\mathrm{n}}$ tertinggi tertinggi diperoleh pada bulan Mei dan September (Gambar 2 dan 3). Nilai $K_{n}$ ikan ekor kuning berkisar antara 1,492,21 dengan rata rata 2,01. Berdasarkan nilai IKG dan $\mathrm{K}_{\mathrm{n}}$ diduga ikan ekor kuning dapat memijah lebih dari satu kali setiap tahunnya. Peningkatan nilai faktor kondisi terjadi pada saat ikan mengisi gonadnya dengan sel kelamin, dan akan mencapai puncaknya sebelum terjadi pemijahan.

Faktor kondisi menunjukkan keadaan ikan dilihat dari kapasitas fisik untuk kelangsungan hidup dan reproduksi dan dari segi komersil berupa kualitas dan kuantitas daging ikan untuk dikonsumsi (Effendie, 2002). Faktor kondisi ikan ekor kuning berkisar antara 1,49-2,21 dengan rata rata 2,01. Nilai tertinggi terdapat pada bulan Mei dan September dan terendah pada bulan Maret (Gambar 5).

Tabel 1. Tingkat kematangan gonad ikan ekor kuning betina menurut bulan pengamatan

Table 1. Gonadal maturity stage by month for yellowtail fusilier females

\begin{tabular}{lrrrrrr}
\hline \multirow{2}{*}{ Bulan/Month } & \multicolumn{7}{c}{ Betina (Female) } \\
\cline { 2 - 7 } \multicolumn{1}{c}{ I } & \multicolumn{1}{c}{ II } & III & IV & V/spent & N \\
\hline Januari & 69,6 & 30,4 & - & - & - & 56 \\
Februari & 58,8 & 25,0 & 13,2 & 2,9 & - & 68 \\
Maret & 78,8 & 7,7 & 13,5 & - & - & 52 \\
April & 43,5 & 26,1 & 23,9 & 6,5 & - & 46 \\
Mei & 61,0 & 12,2 & 12,2 & 8,5 & 6,1 & 82 \\
Agustus & 21,2 & 51,5 & 27,3 & - & - & 33 \\
September & 67,3 & 19,4 & 5,1 & 4,1 & 4,1 & 98 \\
\hline N (ekor) & 263 & 96 & 51 & 16 & 9 & 435 \\
\hline N persen $(\%)$ & 60,5 & 22,1 & 11,7 & 3,7 & 2,1 & 100,0 \\
\hline
\end{tabular}




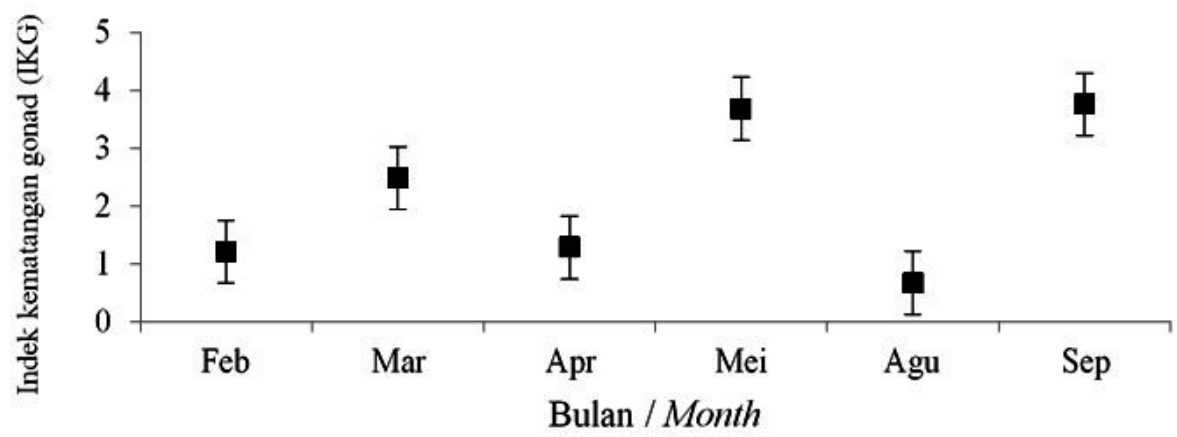

Gambar 2. Indeks kematangan gonad ikan ekor kuning betina berdasarkan waktu pengamatan.

Figure 2. The gonadal maturation index by month for yellowtail fusilier females.

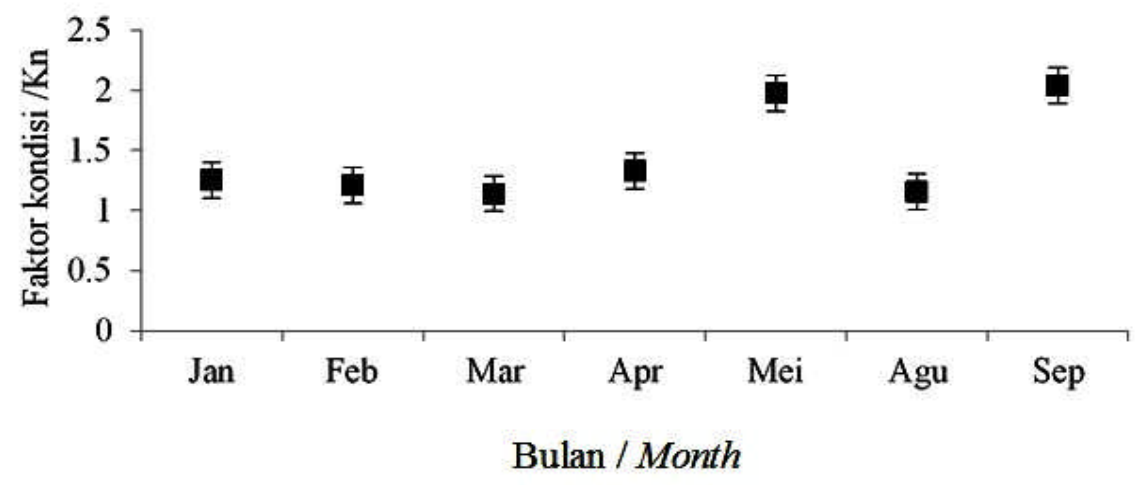

Gambar 3. Nilai faktor kondisi ikan ekor kuning berdasarkan waktu pengamatan.

Figure 3. The condition factor values by month for yellowtail fusilier females.

\section{Potensi Reproduksi}

Fekunditas ikan ekor kuning di perairan Natuna berkisar antara 13.355-151.632 butir dengan rata-rata 59.279 butir. Berdasarkan hasil analisis hubungan fekunditas (F) dengan panjang tubuh $(\mathrm{L})$ diperoleh persamaan $\mathrm{F}=18,15 * \mathrm{~L}^{2,625}$ dengan nilai koefisien korelasi (r) sebesar 0,452 yang berarti hubungan panjang total dan fekunditas ikan ekor kuning adalah kurang erat (Gambar 4). Rata-rata ukuran diameter telur berkisar antara $0,6-4,60 \mathrm{~mm}$ atau ratarata $2,43 \mathrm{~mm}$. Hasil pengamatan diameter telur berdasarkan panjang ikan diterakan pada Gambar 5 . Semakin panjang ukuran ikan, maka diameter telur semakin besar pula.

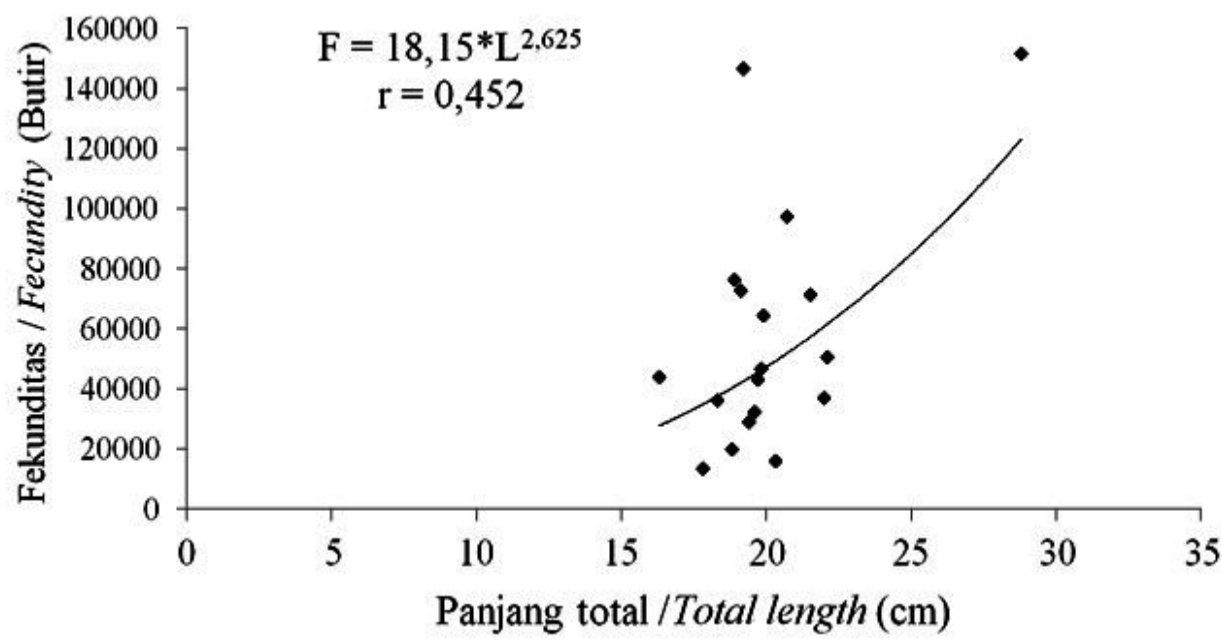

Gambar4. Grafik hubungan fekunditas dengan panjang ikan ekor kuning.

Figure 4. Fecundity-total length relationship for yellowtail fusilier. 


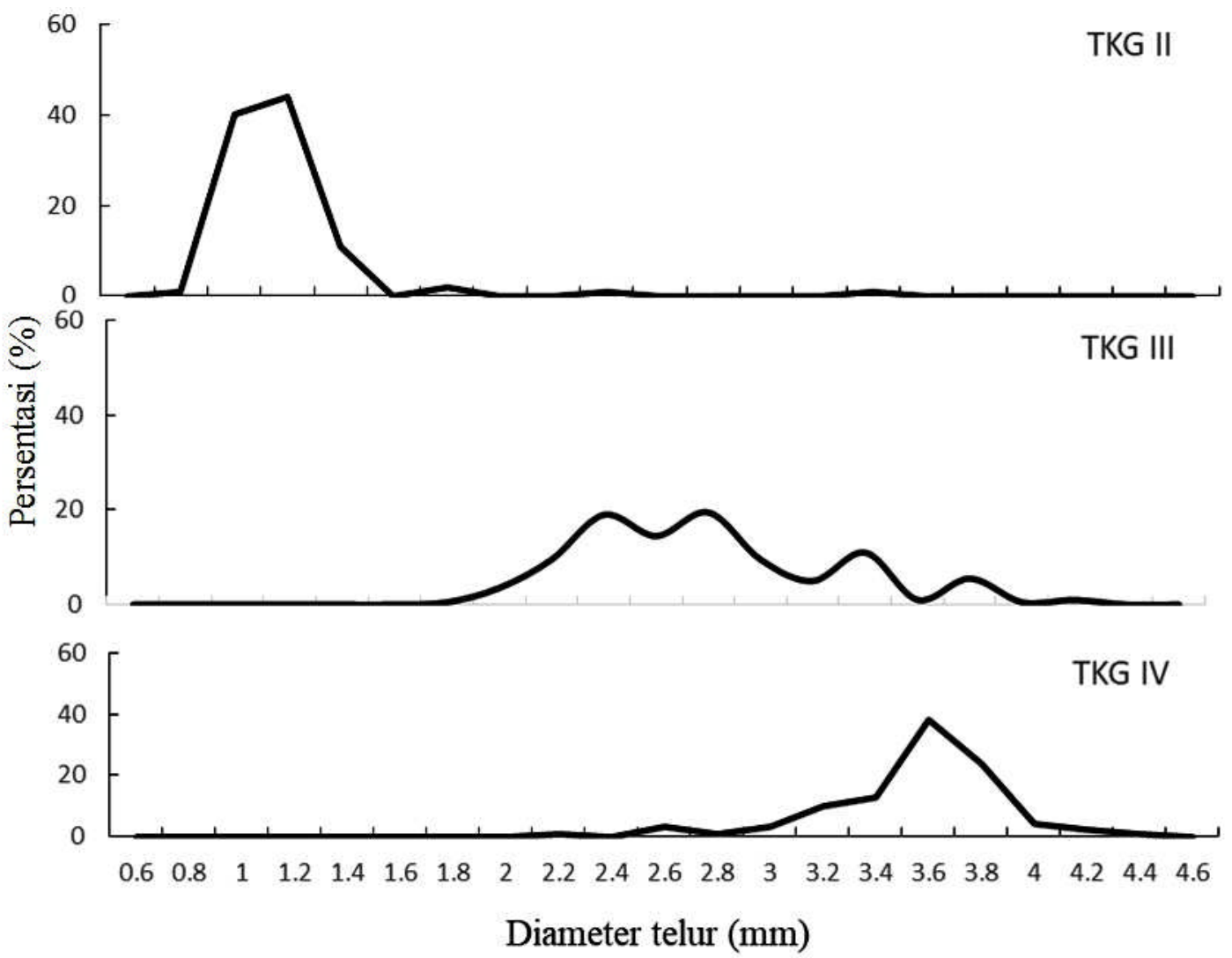

Gambar 5. Frekuensi diameter telur ikan berdasarkan ukuran panjang ikan dan TKG.

Figure 5. Frequency of eggs diameter by length and gonadal maturity stage.

\section{Ukuran Pertama Kali Tertangkap dan Matang Gonad}

Dalam pengelolaan sumberdaya ikan, pengukuran panjang pertama kali tertangkap merupakan hal yang penting dipelajari untuk dapat dihubungkan dengan panjang pertama kali matang gonad. Berdasarkan analisis, rata-rata pertama kali tertangkap dengan bubu $\left(\mathrm{L}_{\mathrm{c}}\right)$ ikan ekor kuning yang didaratkan di Kijang pada panjang 23,00
cmTL (Gambar 6). Ikan ekor kuning betina mengalami pertama kali matang gonad $\left(\mathrm{L}_{\mathrm{m}}\right)$ dengan menggunakan metode Udupa (1986) adalah 25,9 cmTL Data ukuran panjang ikan ekor kuning sebagaimana pada Lampiran 1, tampak bahwa modus panjang ikan yang tertangkap setiap bulannya rata-rata kurang dari $83 \%$ dari ukuran pertama kali matang gonad $\left(\mathrm{L}_{\mathrm{m}}\right)$. Bahkan pada bulan Juli semua sampel $(100 \%)$ ikan yang tertangkap berukuran lebih kecil dari nilai $\mathrm{L}_{\mathrm{m}}$.

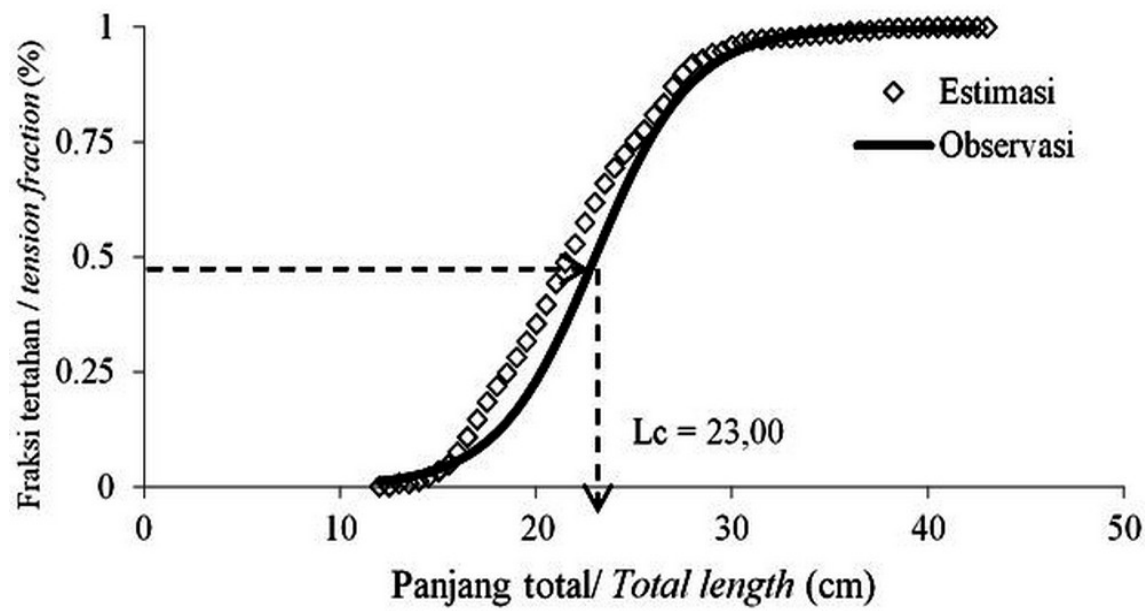

Gambar 6. Ogiv seleksi alat untuk ikan ekor kuning yang ditangkap dengan bubu jaring berukuran mata 2 inci. Rata-rata ikan pertama kali tertangkap (Lc) yang ditunjukkan dengan garis putus-putus adalah $23 \mathrm{cmTL}$.

Figure 6. Ogive selection gear for yellowtail fusilier caught by 2 inches coarse mesh net. The mean length at firts capture shown by the broken line, is Lc $=23 \mathrm{cmTL}$. 


\section{Pertumbuhan}

Hubungan Panjang-Berat

Hubungan panjang-berat dapat digunakan untuk mengetahui sifat pertumbuhan ikan. Dengan tidak membedakan jenis kelaminnya, analisis hubungan panjang-berat ikan yang diamati diperoleh konstanta a sebesar 0,008 dan b sebesar 3,129, sehingga persamaan hubungan panjang-beratnya adalah $\mathrm{W}=0,008 \mathrm{~L}^{3.129}$ (Gambar 7). Dengan uji-t pada taraf nyata $95 \%$ dari nilai b terhadap 3 diperoleh nilai $\mathrm{t}_{\text {hitung }}=0,03$ dan $\mathrm{t}_{\text {tabel }}=1,64$. Dengan demikian maka diterima nilai $b=3$ atau pola pertumbuhan ikan bersifat isometrik, dimana laju pertumbuhan panjang seimbang dengan laju pertambahan beratnya.

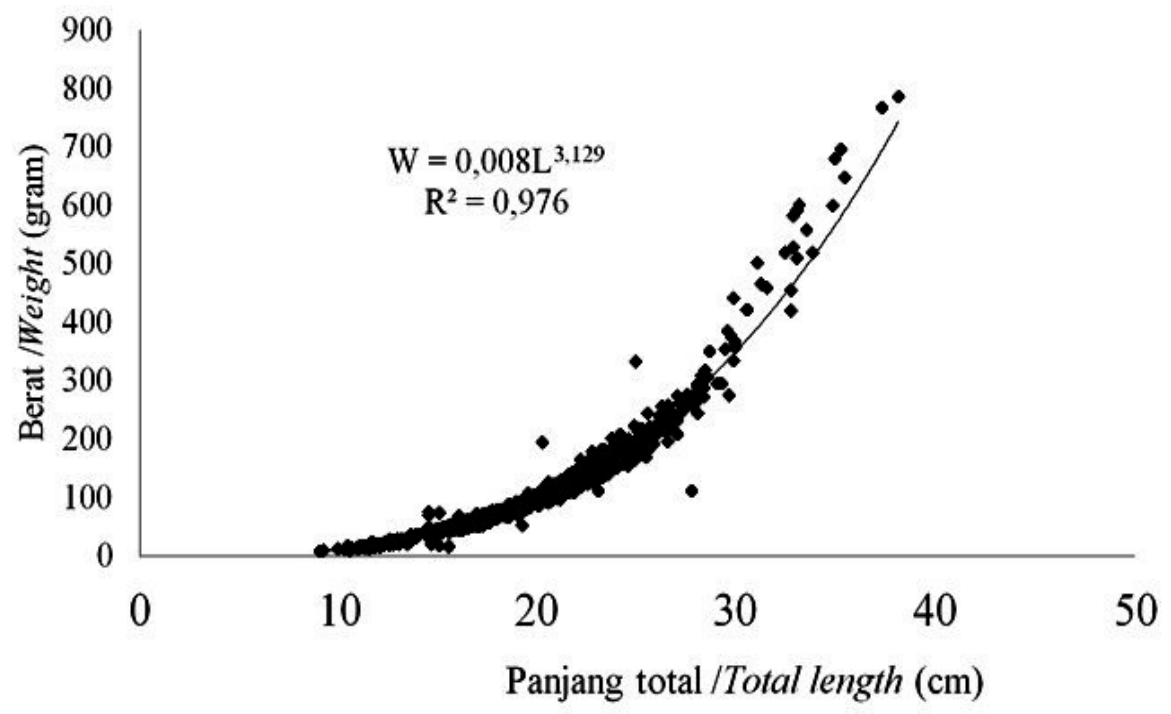

Gambar 7. Grafik hubungan panjang-berat ikan ekor kuning.

Figure 7. Length-weight relationship for yellowtail fusilier.

Sebaran Ukuran Panjang

Dengan memperhatikan Gambar 8, analisis gerak maju modus menggunakan metode Battacharya diperoleh struktur populasi ikan ekor kuning terdiri dari beberapa kelompok umur (kohort) dengan modus nilai tengah panjang total $15 \mathrm{~cm}, 18 \mathrm{~cm}, 23 \mathrm{~cm}$ dan $26 \mathrm{~cm}$. Berdasarkan jenis kelaminnya, sebaran ukuran panjang ikan jantan berkisar antara 11,7-38,1 cmTL dengan rata-rata 18,76 cmTL dan sebaran ikan betina berkisar antara 12,7-34,8 cmTL dengan rata-rata 20,84 cmTL (Gambar 9). Perkembangan sebaran ukuran menurut waktu pengamatan (bulan) dikemukakan pada Gambar 9.

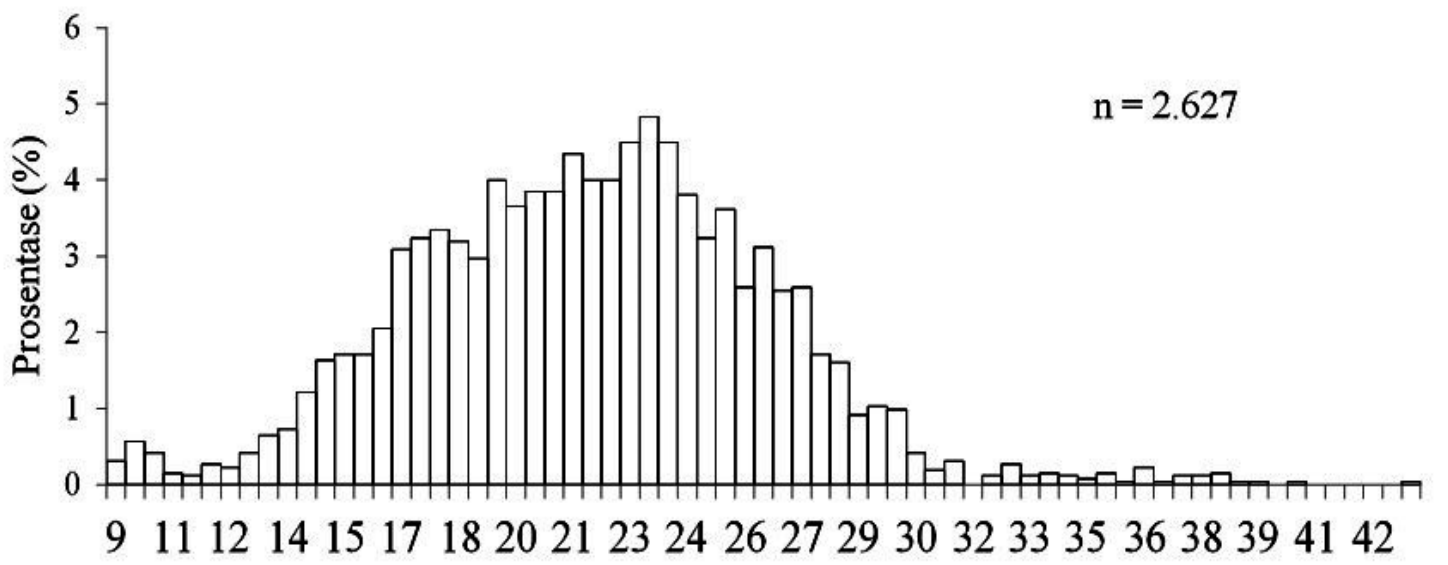

\section{Nilai tengah/ mid length (cmTL)}

Gambar 8. Frekuensi distribusi panjang total (\%) ikan ekor kuning di perairan Natuna, Januari-Nopember 2014.

Figure 8. The length-frequency distributions (\%) for yellowtail fusilier in Natuna waters, January-November 2014. 


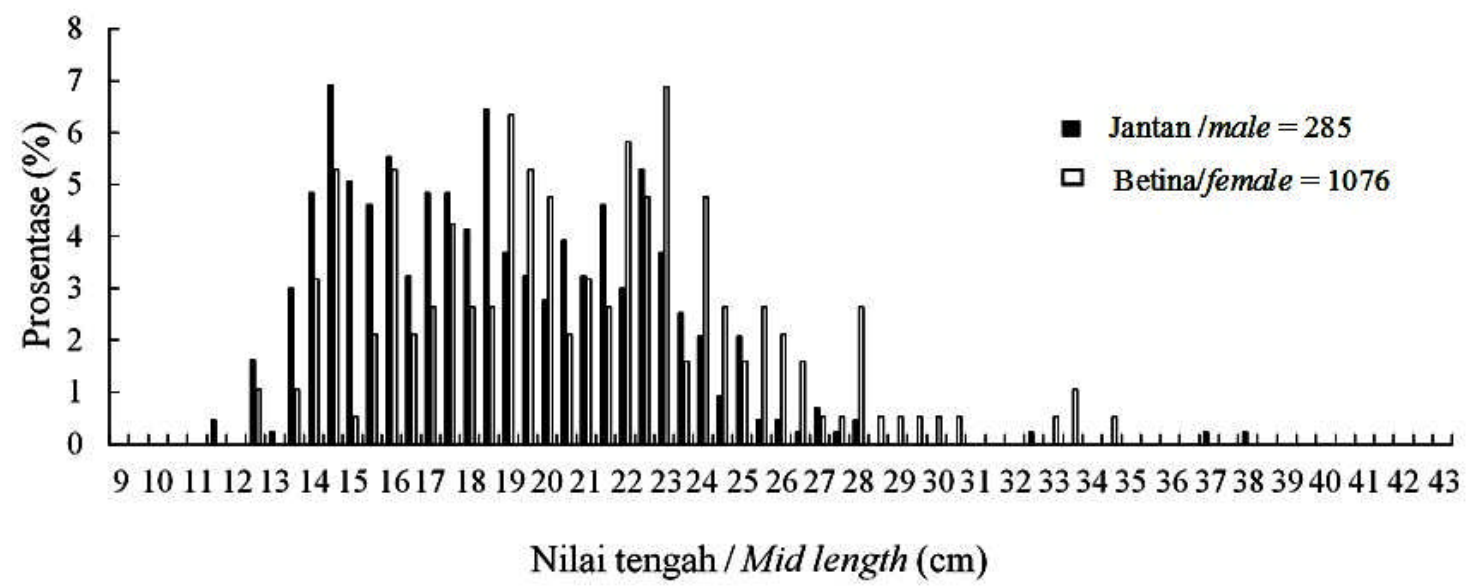

Gambar 9. Frekuensi distribusi panjang total (\%) ikan ekor kuning menurut jenis kelaminnya.

Figure 9. The length-frequency distributions by sexes for yellowtail fusilier.

Pertumbuhan populasi ikan ekor kuning ditunjukkan oleh adanya pergeseran modus panjang dari bulan ke bulan berikutnya dan kelompok ukuran/umur (kohort) yang memasuki kedalam populasi ikan (Gambar 10). Pada bulan Maret, modus berada pada panjang total $15,8 \mathrm{~cm}$. Bulan April, Mei dan Juni, ukuran ikan yang tertangkap bertambah besar ditunjukan oleh pergeseran modus yaitu masing-masing 22,8 cm;26,3 cm dan 23,3 cm. Pada bulan Juli diperkirakan ikan-ikan muda kelompok umur (kohort) berikutnya memasuki populasi ikan, yaitu pada modus panjang total 18,8 cm. Pada bulan Agustus diperoleh modus panjang total $25,3 \mathrm{~cm}$. pada bulan September terdapat kelompok umur berikutnya yang masuk ke dalam populasi dan diperoleh modus pada panjang total 15,3 $\mathrm{cm}$, diikuti dengan pertumbuhan seterusnya sehingga pada bulan Oktober diperoleh modus panjang ikan yang tertangkap $26,3 \mathrm{~cm}$.

\section{Parameter Pertumbuhan}

Dengan menggunakan program ELEFAN-1 diperoleh nilai koefesien laju pertumbuhan $(=\mathrm{K})$ ikan ekor kuning sebesar 0,6/tahun, panjang asimtotis $\left(=\mathrm{L}_{\infty}\right)$ sebesar 43,21 cmTL dan umur teoritis pada saat panjang ikan sama dengan nol $\left(=\mathrm{t}_{\mathrm{o}}\right)$ adalah $-0,24 /$ tahun. Dengan demikian diperoleh persamaan pertumbuhan von Bertalanffy sebagai $\mathrm{L}_{\mathrm{t}}=43,21\left(1-\mathrm{e}^{-0,6(\mathrm{t}-0,24)}\right)$. Berdasarkan persamaan tersebut dapat dibuat suatu kunci hubungan antara panjang dengan umur ikan berdasarkan variasi umurnya.

Mortalitas

Laju kematian total (sebagai slope) diestimasi dari kurva hasil tangkapan yang sudah dilinierkan dengan menggunakan parameter pertumbuhan, $\mathrm{K}$ dan $\mathrm{L}_{\infty}$ sebagai bahan masukannya (Gambar 11). Hasil analisis diperoleh laju kematian total (Z) sebesar 2,38/tahun. Dengan menggunakan rumus Empiris Pauly (1983) dan suhu ratarata di perairan Natuna sebesar $29,8{ }^{\circ} \mathrm{C}$ (Amri \& Restiningsih, 2015), maka diperoleh laju kematian alami (=M) sebesar 1,17/tahun, sehingga diperoleh nilai laju kematian karena penangkapan (=F) sebesar 1,21/tahun. Selanjutnya dengan membandingkan nilai $\mathrm{F}$ terhadap $\mathrm{Z}$ diperoleh nilai laju eksploitasi (exploitation rate, E) sebesar 0,58. 


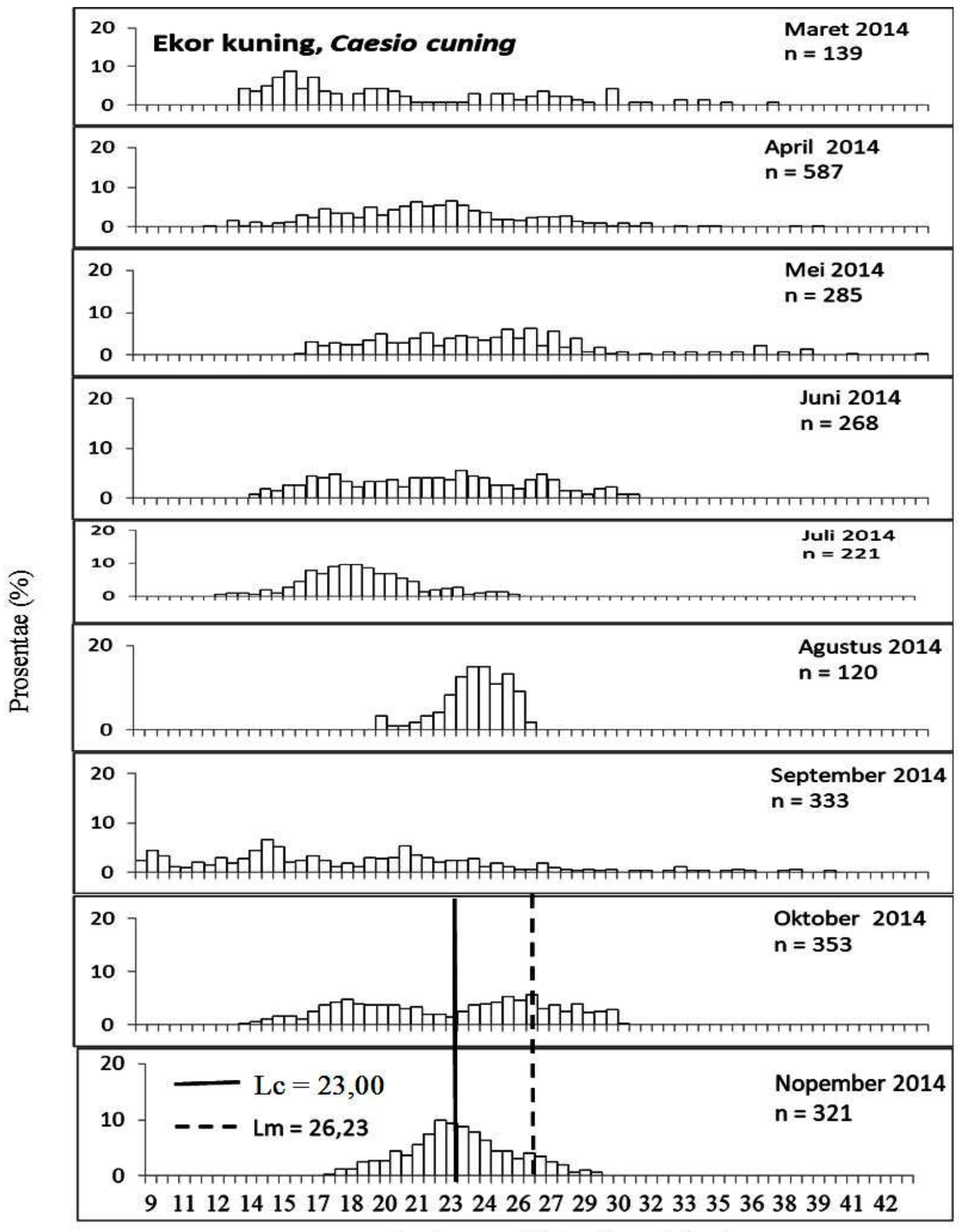

\section{Panjang total/Total length $(\mathrm{cm})$}

Gambar 10. Sebaran ukuran panjang setiap bulan, nilai rata-rata ukuran ikan pertama kali tertangkap $\left(\mathrm{L}_{\mathrm{c}}\right)$ dan pertama kali matang gonad $\left(\mathrm{L}_{\mathrm{m}}\right)$ ikan ekor kuning di Laut Natuna.

Figure 10. Monthly length distributions, length at first capture $\left(L_{c}\right)$ and length at first maturity $\left(L_{m}\right)$ for yellowtail fusilier in Natuna waters. 


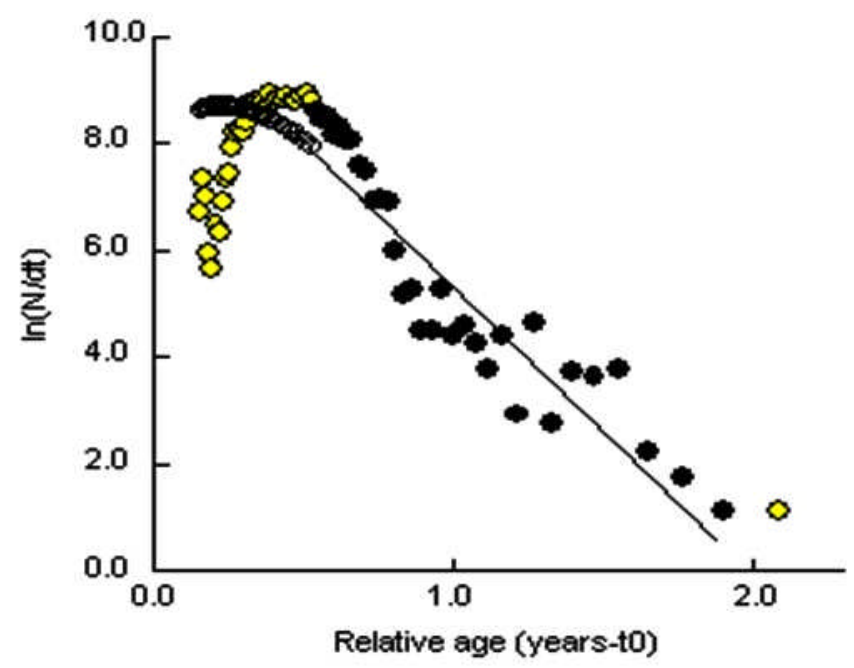

Gambar 11. Nilai mortalitas total ( $Z=2,38 /$ th) sebagai kemiringan kurva konversi hasil tangkapan dengan panjang total ikan ekor kuning.

Figure 11. The value of total mortality $(Z=2.38 / y r)$ as the slope of total length converted catch curve for yellowtail fusilier.

\section{Bahasan}

Perkembangan tingkat kematangan gonad (TKG) digunakan untuk memperoleh informasi waktu dimulainya ikan memijah atau sudah selesai memijah (Effendie, 1997). Berdasarkan komposisi perkembangan TKG setiap bulannya (Tabel 1) maka musim pemijahan ikan ekor kuning terjadi pada bulan Mei dan September. Peningkatan nilai IKG seiring dengan meningkatnya TKG. Hal ini dikarenakan dengan meningkatnya TKG maka ukuran diameter telur dan bobot gonad juga meningkat. Meningkatnya bobot gonad menyebabkan nilai IKG meningkat. Indek kematangan gonad (IKG) dan faktor kondisi $\left(\mathrm{K}_{\mathrm{n}}\right)$ juga tinggi pada bulan Mei dan September. Menurut Effendie (1997) bahwa bobot gonad mencapai maksimum sesaat sebelum ikan memijah dan disertai dengan nilai IKG yang mencapai maksimum pada kondisi tersebut.

Berdasarkan Gambar 2 dan 3, musim pemijahan ikan ekor kuning diprediksi dua kali dalam setahun yaitu mulai bulan Mei dan September hingga 1 atau 2 bulan berikutnya (Juni-Juli atau Oktober-Nopember). Oleh karena itu untuk tujuan pengelolaan disarankan nelayan di sekitar Natuna untuk tidak melakukan penangkapan ikan ekor kuning pada bulan Juni-Juli atau Oktober-Nopember. Namun hal ini masih memerlukan penelitian seksama. Peneliti Habibun (2011) menyatakan musim pemijahan ikan ekor kuning di perairan Kepulauan Seribu terjadi pada bulan FebruariApril.

Selain kematangan gonad, potensi reproduksi ikan dan penambahan baru sebagai hasil pemijahan dapat dianalisis dari jumlah telurnya (fekunditas). Disebutkan bahwa fekunditas meningkat seiring dengan pertambahan panjang dan bobot ikan (Karyaningsih et al., 1992;
Rahardjo et al., 2011). Umumnya ikan Teleostei yang hidup di laut memiliki tingkat fekunditas tinggi, mencapai ribuan sampai jutaan telur yang dihasilkan oleh setiap ekor ikan betina yang memijah setiap tahunnya. Fekunditas ikan ekor kuning di perairan Natuna berkisar antara 13.355151.632 butir. Nilai ini lebih tinggi dari fekunditas ikan ekor kuning di Kepulauan Seribu yaitu antara 4.513-38.702 butir (Habibun, 2011). Nilai fekunditas yang tinggi ini menunjukkan potensi reproduksi yang tinggi pula, sehingga berpengaruh pada jumlah stok dan individu baru (rekrutmen) di perairan Laut Natuna.

Analisis hubungan antara fekunditas dengan panjang ikan ekor kuning di perairan Natuna diperoleh koefisien korelasi (r) sebesar 0,452 (Gambar 6). Hal ini berarti korelasi antar keduanya tidak begitu erat. Rendahnya korelasi ini diduga disebabkan karena variasi fekunditas memiliki ukuran panjang yang hampir sama bahkan sebagian besar memiliki ukuran yang sama. Fekunditas terendah terdapat pada ikan dengan ukuran panjang 17,8 cmTL dan tertinggi pada panjang $28,8 \mathrm{cmTL}$. Hal ini menunjukkan bahwa ikan ekor kuning memiliki beberapa kelompok ukuran. Hal ini sesuai dengan pernyataan Effendie (2002) bahwa variasi jumlah telur ikan dapat disebabkan karena adanya variasi kelompok ukuran ikan. Menurut Tang \& Affandi (2001), kematangan gonad yang berhubungan dengan fekunditas setiap spesies tidak sama ukurannya, demikian juga dengan ikan yang spesiesnya sama. Ikan dengan ukuran panjang dan gonad tertentu, walaupun ukuran panjangnya bertambah, belum tentu diikuti dengan bertambahnya ukuran gonad. Perbedaan fekunditas pada setiap ukuran ikan antara lain disebabkan oleh ikan muda yang memiliki fekunditas maksimal dibandingkan ikan tua, kualitas telur terutama isi kuning telurnya, kandungan makanan, predator dalam jumlah besar dan kondisi lingkungan (Effendie, 2002). 
Parameter lain yang penting dalam menentukan potensi reproduksi ikan adalah variasi diameter telur pada ovariumnya. Diameter telur dipengaruhi oleh jumlah makanan untuk proses metabolismenya (Nikolsky, 1963). Hasil pengamatan menunjukkan diameter telur ikan ekor kuning di Natuna ukurannya bertambah bersamaan dengan pertambahan ukuran panjang dan perkembangan gonadnya (Gambar 7). Penyebaran diameter telur ikan pada gonad yang sudah matang juga dapat menduga pola pemijahan dengan melihat modus penyebarannya. Pada TKG II memiliki puncak diamater telur pada ukuran 1,20 $\mathrm{mm}$, TKG III memiliki dua puncak ukuran diameter telur (2,4 dan 2,6 mm) dan TKG IV terdiri dari 1 puncak yaitu ukuran diameter telur 3,6 mm. Dengan demikian maka tipe pemijahannya adalah pemijahan total (total spawner) artinya pemijahan ikan dilakukan dengan mengeluarkan telur masak secara keseluruhan pada satu waktu musim pemijahan, dan akan melakukan pemijahan kembali pada musim pemijahan berikutnya. Distribusi diameter telur dengan modus yang berbeda, modus pertama terdapat pada ikan yang belum matang gonad dan modus berikutnya pada ikan yang sudah matang gonad (Effendie, 2002).

Berdasarkan metode Udupa (1986), nilai panjang pada pertama kali matang gonad $\left(\mathrm{L}_{\mathrm{m}}\right)$ ikan ekor kuning di Natuna sebesar 25,9 cmTL. Nilai ini lebih besar dari panjang pertama kali tertangkap $\left(\mathrm{L}_{\mathrm{m}}=25,9 \mathrm{~cm} \geq \mathrm{L}_{\mathrm{c}}=23,00 \mathrm{~cm} \mathrm{TL}\right)$. Ditinjau dari segi pengelolaan, maka hal ini kurang baik untuk keberlangsungan ikan ekor kuning tersebut, dimana ikan banyak tertangkap sebelum melakukan proses pemijahan atau tidak memberi kesempatan .untuk bereproduksi. Hal ini diduga karena pemasangan bubu ikan dan penangkapan ikan dengan pancing dilakukan pada daerah asuhan (nursery ground) atau daerah mencari makan (feeding ground) ikan. Terkait dengan hal tersebut, maka pengoperasian bubu hendaknya memperhatikan musim pemijahan dan lokasi daerah asuhan ikan ekor kuning. Disarankan untuk tidak menangkap ikan pada bulan Juli-Agustus, karena pada saat itu hasil tangkapan didominasi oleh ikan berukuran relatif kecil, belum matang gonad (immature) atau belum sempat memijah. Sebaliknya, pada bulan Maret-Mei ukuran ikan yang tertangkap relatif lebih besar bahkan diantaranya sudah banyak yang memijah.

Pertumbuhan memiliki karakteristik yang berbeda pada masing-masing kelompok jenis ikan. Menurut Sparre \& Venema (1999), pertumbuhan ikan berhubungan dengan ukuran panjang ikan, sedangkan panjang ikan dapat merupakan fungsi umur. Hasil analisis hubungan panjangberat ikan ekor kuning di perairan Natuna memperlihatkan pola pertumbuhan yang bersifat isometrik yang berarti pertambahan panjang ikan seimbang dengan pertambahan beratnya. Menurut Effendie (2002), perbedaan pola pertumbuhan ikan dapat dipengaruhi oleh faktor keturunan, jenis kelamin, umur, parasit, penyakit, ketersediaan makanan dan suhu perairan serta kematangan gonad. Selanjutnya Harmiyati (2009) menambahkan bahwa perbedaan nilai koefisien regresi (b) juga dapat disebabkan oleh perbedaan jumlah dan variasi ukuran ikan yang diamati.

Di perairan Natuna, ukuran ikan betina yang tertangkap umumnya lebih besar daripada jantannya (Gambar 9). Hasil yang lain diperoleh dari hasil penelitian Nirmalasari (2016) di perairan Takalar dan Sinjai, Sulawesi Selatan, dimana pada pengukuran morfometrik dan meristik menunjukkan ikan ekor kuning jantan lebih panjang. Lagler et al., (1977) menyebutkan perbedaan ukuran berdasarkan jenis kelamin ini diduga disebabkan oleh adanya faktor genetik di masing-masing lokasi.

Umumnya ikan ekor kuning yang tertangkap di perairan Natuna memiliki ukuran yang lebih besar dibandingkan dengan ikan dari Kepulauan Seribu, Teluk Jakarta. Hal ini diduga karena perbedaan kelimpahan makanan atau karena perbedaan alat tangkap yang digunakan. Muroami masih banyak digunakan di Kepulauan Seribu, sementara bubu dan pancing ulur yang lebih selektif banyak digunakan di perairan Natuna. Menurut Fredou \& Ferreira (2005) perbedaan karakteristik ekologi, tingkat eksploitasi dan musim penangkapan dapat meyebabkan perbedaan ukuran ikan yang tertangkap. Selanjutnya Fujaya (2004) menambahkan perbedaan ukuran tersebut dapat disebabkan oleh faktor dalam dan faktor luar. Faktor dalam, antara lain meliputi keturunan, jenis kelamin dan umur, sedangkan faktor luar meliputri lokasi pengambilan sampel dan jumlah individu dalam ekosistem terumbu karang yang tidak sebanding dengan jumlah makanan sehingga terjadi kompetisi dalam mendapatkan makanan.

Berdasarkan hasil penelitian, struktur populasi ikan ekor kuning di perairan Laut Natuna terdiri dari beberapa kelompok umur (kohort) pada generasi kelompok ikan muda dan ikan dewasa. Persamaan pertumbuhan von Bartalanffy sebagai $\mathrm{Lt}=43,21\left(1-\mathrm{e}^{-0,6(t-0,24)}\right)$. Nilai $\mathrm{K}$ yang besarnya 0,6 termasuk kategori pertumbuhan lambat. Menurut Sparre \& Venema (1999), ikan yang mempunyai nilai $\mathrm{K}$ tinggi maka mempunyai umur pendek untuk mencapai panjang maksimumnya. Parameter pertumbuhan $\mathrm{K}$ terkait dengan laju metabolik ikan. Spesies ikan pelagis sering lebih aktif dari pada ikan demersal dan memiliki suatu K yang lebih tinggi. Demikian pula ikan-ikan di daerah tropis lebih tinggi daripada ikan ikan-ikan perairan dingin. Penelitian oleh Harmiyati (2009) dan Habibun (2011) diperoleh ukuran panjang asimtotik dan laju pertumbuhan ikan ekor kuning di Kepulauan Seribu nilainya lebih kecil dibandingkan di Laut Natuna. Hal ini diduga adanya tekanan penangkapan di perairan Kepulauan Seribu lebih besar. 


\section{Mortalitas}

Berdasarkan analisis pada kurva konversi hasil tangkapan (Gambar 11), mortalitas karena penangkapan (F) ikan ekor kuning lebih besar dibandingkan mortalitas alaminya. Hal ini mengindikasikan adanya tekanan penangkapan terhadap ikan ekor kuning di perairan Laut Natuna. Menurut (Sparre \& Venema, 1999; Widodo \& Suadi, 2006), aktifitas penangkapan ikan yang intensif menyebakan nilai $\mathrm{F}$ lebih tinggi dibandingkan nilai $\mathrm{M}$. Variasi laju mortalitas total (Z) dari tahun ke tahun banyak dipengaruhi oleh laju mortalias karena penangkapan (F). Sedangkan laju mortalitas alami disebabkan oleh adanya proses pemangsaan termasuk kanibalisme, penyakit, stres karena pemijahan, kelaparan dan ketuaan.

Laju eksploitasi (E) ikan ekor kuning di perairan Laut Natuna adalah 0,58 . Hal ini menunjukkan bahwa tingkat pemanfaatan ikan ekor kuning diperairan tersebut sedikit melebihi nilai laju eksploitasi optimal $(\mathrm{E}=0,5)$. Hal ini sesuai dengan pernyataan (Suman et al., 2015; 2016) bahwa ikan karang di perairan Laut China Selatan pada umumnya masih dapat ditingkatkan pemanfaatannya. Berbeda halnya dengan hasil penelitian Habibun (2011), tingkat pemanfaatan ikan ekor kuning di Kepulauan Seribu sudah terindikasi pada kondisi tangkap lebih (overfishing) dengan nilai $E=0,75$. Perbedaan nilai laju eksploitasi di perairan tersebut diduga oleh intensitas penangkapan dan jenis alat tangkap yang digunakan berbeda.

Beberapa saran dalam pengelolaan yang perlu dilakukan adalah : (1) Pengaturan musim penangkapan ikan (open/closed season). Penutupan penangkapan dilakukan pada bulan Mei dan Agustus bersamaan dengan musim pemijahan; (2) Pengaturan batas ukuran yang boleh ditangkap (minimum legal size). Untuk menjaga kelestarian ikan ekor kuning, sebaiknya ikan-ikan ditangkap pada ukuran lebih besar dari ukuran $\mathrm{L}_{\mathrm{m}}$ yaitu lebih dari $26 \mathrm{cmTL}$; (3) Pengaturan upaya penangkapan dengan memperbesar ukuran mata pancing, modifikasi alat tangkap bubu yaitu dilengkapi dengan pintu pelolosan sehingga ikan berukuran kecil dapat lolos, dan (4) Perlunya menerapkan sistem monitoring dan pendataan secara sistematis guna mendapakan data yang akurat sebagai dasar membuat perencanaan pengelolaan.

\section{KESIMPULAN}

Musim pemijahan ikan ekor kuning (Caesio cuning) di Laut Natuna berlangsung pada bulan Mei dan Agustus, bersifat pemijahan total dan memiliki potensi reproduksi tinggi dengan fekunditas berkisar antara 13.355-151.632 butir telur. Sebagian besar ikan yang tertangkap pada bulan Juli dan Agustus belum sempat melakukan proses pemijahan, dimana panjang pertama memijah lebih besar dari panjang pertama kali tertangkap $\left(\mathrm{L}_{\mathrm{m}}>\mathrm{L}_{\mathrm{c}}\right)$. Sebaran ukuran panjang ikan ekor kuning berkisar antara 9,3 - 43,3 cmTL. Pola pertumbuhannya bersifat isometrik $(b=3,129)$ dimana pertambahan panjang seimbang dengan pertumbuhan beratnya. Laju pertumbuhan ikan relatif lambat ( $K=0,6 /$ tahun). Aktifitas penangkapan yang intensif menyebabkan laju kematian karena penangkapan $(\mathrm{F}=1,21$ / tahun) lebih tinggi dari laju kematian alami ( $M=1,17 /$ tahun). Eksploitasi ikan ekor kuning sudah melebihi upaya optimumnya $(\mathrm{E}=0,58)$.

\section{PERSANTUNAN}

Tulisan ini merupakan hasil dari kegiatan riset "Pengkajian stok dan optimasi pemanfaatan sumberdaya perikanan demersal untuk mendukung industrialisasi di WPP 571-Selat Malaka dan WPP 711 Laut China Selatan” di Balai Penelitian Perikanan Laut. Tahun 2014.

\section{DAFTAR PUSTAKA}

Allen, G., Steene, R., Human, P., \& Loach, N.D. (2007). Reef fish identification tropical pasific (p. 457). New World Publication, Inc. Jacksonville, Florida, USA.

Amri, K. \& Restiningsih,Y.H. (2015). Kondisi oseanografi (suhu permukaan laut dan klorofil-a) Perairan Laut Cina Selatan Berdasarkan Data Multitemporal. Status Pemanfaatan Sumber Daya Ikan di Perairan Laut Cina Selatan(WPP-NRI 711). Penerbit RefGraphika. Jakarta.

[BPPL] Balai Penelitian Perikanan Laut. (2015). Pengkajian stok dan optimasi pemanfaatan sumber daya perikanan demersal untuk mendukung industrialisasi di WPP 571Selat Malaka dan WPP 711 Laut Cina Selatan. Jakarta.

Carpenter, K.E. \& Niem, V.H. (2001). FAO species identification guide for fishery purposes. The living marine resources of the Western Central Pacific, Vol. 5, Bony fishes part 3 (Menidae to Pomacentridae), p. 2876. Rome: FAO of the United Nations.

Effendie, M.I. (1997). Metoda biologi perikanan (p. 112). Bogor (ID): Yayasan Dewi Sri.

Effendie,M.I. (2002). Biologi Perikanan (Revisi) (p. 163). Bogor (ID): Yayasan Pustaka Nusatama.

Estradivari, Syahrir, M., Susilo, N., Yusri, S., \& Timotius, S. (2007). Terumbu karang Jakarta: pengamatan jangka panjang terumbu karang Kepulauan Seribu (2004 - 2005) (p. 87). Jakarta: Yayasan TERANGI.

Fredou T. \& Ferreira, B.P. 2005. Bathymetric trends of Northeastern Brazilian snapper (Pisces, Lutjanidae): Implication for the reef fishery dynamic. Brazilian of Biology and Technology. 48, 787-800. 
Fujaya, Y. (2004). Fisiologi Ikan. Dasar Pengembangan Teknologi Perikanan (p. 224 hal). Rineka Cipta. Jakarta.

Gayanilo, F. C. Jr., Sparre, P., \& Pauly, D. (2005). FAOICLARM stock assessment tools II (FiSAT-II). Revised Version. User's guide. FAO Computerized Information Series (Fisheries). No.8. Revised version. FAO Rome, $168 \mathrm{p}$.

Goddard,S. (1996). Feed management in intensive aquaculture. Fisheries and Marine Institute Memorial University. New Founland, Canada. Chapman \& Hall. New York.

Habibun, E. A. (2011). Aspek pertumbuhan dan reproduksi ikan ekor kuning (Caesio cuning) yang didaratkan di pangkalan pendaratan ikan Pulau Pramuka, Kepulauan Seribu, Jakarta [skripsi]. Bogor: Fakultas Perikanan dan Ilmu Kelautan. IPB.

Harmiyati, D. (2009). Analisis hasil tangkapan sumberdaya ikan ekor kuning (Caesio cuning) yang didaratkan di PPI Pulau Pramuka, Kepulauan Seribu [Skripsi]. Bogor: Fakultas Perikanan dan Ilmu Kelautan. IPB.

Holden M.J. \& Raitt, D. (1974). Manual of fisheries sciences. Part 2. Methods of Resource Investigation and Their Application. FAO Fish.

Lagler, K. F., Bardach, J.E., Miller, R.R., \& Passino, D.R. (1977). Ichtyology (p. 506). John Wiley \& Sons USA.

Karyaningsih, S., Djamal, R., \& Junus, S. (1992). Pengamatan fekunditas dan diameter telur ikan kakap merah (Lutjanus sanguineus). Jurnal Penelitian Perikanan Laut. (68), 67-82.

Nggajo, R. (2009). Keterkaitan sumberdaya ikan ekor kuning (Caesio cuning) dengan karakteristik habitat pada ekosistem terumbu karang di Kepulauan Seribu [tesis]. Sekolah Pascasarjana, Institut Pertanian Bogor. Bogor. $90 \mathrm{hlm}$.

Nikolsky, G. V. (1963). Fish population dynamics oliver and boyd (p. 323p). Edinburg.
Nirmalasari. (2016). Studi morfometrik dan meristik ikan ekor kuning, Caesio cuning (Bloch, 1791) yang didaratkan di tempat pelelangan ikan Beba, Kabupaten Takalar, dan di tempat pelelangan ikan Lappa, Kabupaten Sinjai. [Skripsi]. Fakultas Ilmu Kelautan dan Perikanan-Universitas Hassanuddin. Makassar.

Pauly, D. (1980). A selection of simple methods for the assessment of tropical fish stocks: FAO Fish. Circ., (729): (p.54).

Pauly, D. (1983). Some simple methods for the assessment of tropical fish stock. FAO Fish.Tech.Pap.

Pauly, D. (1984). Fish population dynamics in tropical waters: a manual for use with programmable calculators. ICLARM Stud Rev.

Rahardjo, M.F., Djadja, S.S., Ridwan,A\& Sulistiono. (2011) Iktiologi (p. 394). Lubuk Agung, Bandung.

Sparre P. \& Venema S.C. (1999). Introduksi pengkajian stok ikan tropis. Buku 1: Manual. Widodo J, Merta IGS, Nurhakin S, Badrudin M, Penerjemah. Jakarta: Pusat Penelitian dan Pengembangan Perikanan. Terjemahan dari Introduction to Tropical Fish Stock Assessment. Part I:Manual.

Tang, U. M. \& Affandi, R. (2001). Biologi reproduksi ikan (p, 153). Pusat Penelitian Kawasan Pantai dan Perairan. Universitas Riau. Riau.

Udupa, K.S. (1986). Statistical method of estimating the size of first mature in fishies. Fishbyte. 4(2):8-10.

Widodo, J. \& Suadi. (2006). Pengelolaan sumberdaya perikanan laut (p. 252). Gajah Mada University Press. Yogyakarta.

Suman, A., Haluan, J., Yunaspi, Efizon, D., Bintoro, G. \& Amri,K. (2015). Status pemanfaatan sumber daya ikan di Perairan Laut China Selatan (WPP-NRI 711). Cetakan I. Ref Graphika-Jakarta.

Suman, A., Irianto., H.E., Satria, F. \& Amri, K. (2015). Potensi dan tingkat pemanfaatan sumberdaya ikan di Wilayah Pengelolaan Perikanan Negara Republik Indonesia (WPP NRI) Tahun 2015 serta opsi pengelolaannya. $J$. Kebijak.Perikan.Ind. 8(2), 97-110. 
Lampiran 1. Prosedur penghitungan estimasi panjang pertama kali matang gonad $\left(\mathrm{L}_{\mathrm{m}}\right)$ ikan ekor kuning (Udupa, 1986) Apendix 1. Calculation procedures for the estimation of length at first maturity $\left(L_{m}\right)$ for yellowtail fusilier (Udupa, 1986)

\begin{tabular}{|c|c|c|c|c|c|c|}
\hline \multirow{2}{*}{$\begin{array}{c}\text { Tengah kelas } \\
\text { panjang / } \\
\text { Mid length }\end{array}$} & \multirow{2}{*}{$\begin{array}{l}\text { Log tengah } \\
\text { kelas/Log mid } \\
\text { length }\end{array}$} & $\begin{array}{c}\text { Jumlah } \\
\text { sampel ikan / } \\
\text { Number of } \\
\text { samples }\end{array}$ & \multirow{2}{*}{$\begin{array}{c}\text { Jumlah } \\
\text { ikan belum } \\
\text { matang/ } \\
\text { Number of } \\
\text { immature } \\
\text { stages }\end{array}$} & \multirow{2}{*}{$\begin{array}{c}\text { Jumlah ikan } \\
\text { matang / } \\
\text { Number of } \\
\text { mature stages } \\
\mathbf{r}_{\mathbf{i}}\end{array}$} & \multirow{2}{*}{$\begin{array}{c}\text { Proporsi ikan } \\
\text { matang / } \\
\text { Mature } \\
\text { proportion } \\
\text { p }_{\mathbf{i}}\end{array}$} & \multirow[b]{2}{*}{ 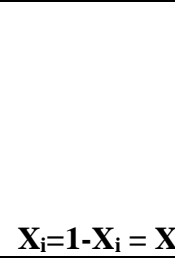 } \\
\hline & & $\mathbf{n}_{\mathbf{i}}$ & & & & \\
\hline 14 & 1,1461 & 27 & 27 & 0 & 0,0000 & 0,0280 \\
\hline 15 & 1,1761 & 13 & 13 & 0 & 0,0000 & 0,0263 \\
\hline 16 & 1,2041 & 23 & 22 & 1 & 0,0435 & 0,0248 \\
\hline 17 & 1,2304 & 21 & 17 & 4 & 0,1905 & 0,0235 \\
\hline 18 & 1,2553 & 20 & 8 & 12 & 0,6000 & 0,0223 \\
\hline 19 & 1,2788 & 27 & 2 & 25 & 0,9259 & 0,0212 \\
\hline 20 & 1,3010 & 7 & 0 & 7 & 1,0000 & 0,0202 \\
\hline 21 & 1,3222 & 16 & 2 & 14 & 0,8750 & 0,0193 \\
\hline 22 & 1,3424 & 10 & 0 & 10 & 1,0000 & 0,0185 \\
\hline 23 & 1,3617 & 9 & 1 & 8 & 0,8889 & 0,0177 \\
\hline 24 & 1,3802 & 6 & 1 & 5 & 0,8333 & 0,0170 \\
\hline 25 & 1,3979 & 2 & 0 & 2 & 1,0000 & 0,0164 \\
\hline 26 & 1,4150 & 0 & 0 & 0 & 0,0000 & 0,0158 \\
\hline 27 & 1,4314 & 0 & 0 & 0 & 0,0000 & 0,0152 \\
\hline 28 & 1,4472 & 1 & 0 & 1 & 1,0000 & 0,0147 \\
\hline 29 & 1,4624 & 2 & 0 & 2 & 1,0000 & 0,0142 \\
\hline 30 & 1,4771 & 0 & 0 & 0 & 0,0000 & 0,0138 \\
\hline 31 & 1,4914 & 1 & 0 & 1 & 1,0000 & 0,0134 \\
\hline 32 & 1,5051 & 1 & 0 & 1 & 1,0000 & 0,0130 \\
\hline 33 & 1,5185 & 1 & 1 & 0 & 0,0000 & 0,0126 \\
\hline 34 & 1,5315 & 0 & 0 & 0 & 0,0000 & 0,0122 \\
\hline 35 & 1,5441 & 0 & 0 & 0 & 0,0000 & 0,0119 \\
\hline 36 & 1,5563 & 0 & 0 & 0 & 0,0000 & 0,0116 \\
\hline 37 & 1,5682 & 0 & 0 & 0 & 0,0000 & 0,0113 \\
\hline 38 & 1,5798 & 0 & 0 & 0 & 0,0000 & 0,0110 \\
\hline 39 & 1,5911 & 0 & 0 & 0 & 0,0000 & 0,0000 \\
\hline 40 & 1,6021 & 3 & 1 & 2 & 0,6667 & 0,0000 \\
\hline
\end{tabular}

$\mathrm{m}=\mathrm{X}_{\mathrm{k}}+\mathrm{X} / 2-\left(\mathrm{X} \sum \mathrm{p}_{\mathrm{i}}\right)$

12,0238

$\mathrm{m}=1,6021+(0,0164 / 2)-(0,0164 * 12,0238)$

$$
\mathrm{m}=1,4133
$$

$\operatorname{Antilog}(1,4133)=25,9$

Panjang ikan pertama kali matang gonad $(\mathrm{Lm})=25,9 \mathrm{~cm}$ 